\title{
Extended blood group profiles for Malays, Chinese, and Indians in Peninsular Malaysia
}

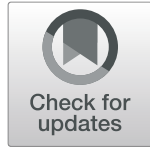

\author{
Che Ghazali Norul Hajar ${ }^{1,2}$, Zulkafli Zefarina ${ }^{2,3}$, Nor Suhaila Md. Riffin ${ }^{4}$, Tuan Hulwani Tuan Mohammad ${ }^{5}$, \\ Mohd Nazri Hassan ${ }^{2,3}$, Prathapan Poonachi', Sabreena Safuan ${ }^{1}$, Gehad ElGhazali ${ }^{6}$, Geoffrey Keith Chambers ${ }^{7}$ and \\ Hisham Atan Edinur ${ }^{1,2,8,9^{*}}$ (D)
}

\begin{abstract}
Background: Blood group antigens are immunogenic polymorphic molecules presented on the surface of RBCs. This study aimed to determine extended blood group profiles (ABO, Rhesus, Kell, Kidd, Duffy, MNS, Cartwright, Dombrock, Colton, Lutheran, and Vel) in Malays, Chinese, and Indians in Peninsular Malaysia.

Results: Here, ABO Type O, DCCee, MNs, and Fy (a+b-) were the most frequent major blood group phenotypes in all three ethnic groups. Other minor blood group systems distributed differently across these ethnic groups, except for the Kell, Lutheran, Cartwright, and Vel blood group systems, where only K-k+, Lu (8+14), Yt (a+b-), and Vel (+) phenotypes were observed. Exact tests of population differentiation generally showed no significant differences between Malays included in the present study vs. other ethnically similar datasets from previous surveys. However, many significant differences were recorded in comparison between blood group datasets from ethnically unrelated populations (Malays vs. Chinese vs. Indians) especially for Rhesus, Kidd, and Duffy blood group systems. A Principal component analysis (PCA) plot showed that population groups from the Peninsular Malaysia map closely together as compared with population groups from other geographical regions.
\end{abstract}

Conclusions: Overall, our present study has successfully provided an extended blood group profiles for Malays, Chinese, and Indians in Peninsular Malaysia. These new blood group datasets can be used as guidelines for donor recruitment and as reference standards for studying diseases associated with blood group systems.

Keywords: Blood group, RBCs, Peninsular Malaysia, Malays, Chinese, Indians

\section{Background}

Blood group antigens are polymorphic and immunogenic molecules found on the surface of red blood cells (RBCs) [1]. Antibodies against blood group antigens can develop naturally following exposure to blood group-like substances from viruses or bacteria or immune antibodies due to gestation or transfusion incompatibilities. Most of the naturally occurring antibodies include anti$\mathrm{Cw}$, anti-M, and antibodies in the $\mathrm{Ii}$, Lewis, and $\mathrm{P}$

\footnotetext{
* Correspondence: edinur@usm.my

${ }^{1}$ School of Health Sciences, Universiti Sains Malaysia, Health Campus, Kubang Kerian, Kelantan, Malaysia

${ }^{2}$ Hospital Universiti Sains Malaysia, Universiti Sains Malaysia, Kubang Kerian, Kelantan, Malaysia

Full list of author information is available at the end of the article
}

systems are not clinically significant, except for $A B O$ antibodies. Furthermore, immune antibodies are clinically significant and produced specifically against RBC antigens such as antibodies in the K, Rh, Duffy, and Kidd systems [1-3]. From a total of $360 \mathrm{RBC}$ antigens recognized by the International Society of Blood Transfusion (ISBT), 330 were grouped into 39 blood group systems [4]. However, standard transfusion practice only requires matching for $\mathrm{ABO}$ and Rhesus-compatible $\mathrm{RBC}$ units between donor and patient because transfusion of $\mathrm{ABO}$ and Rhesus-incompatible blood can cause haemolytic transfusion reaction, which is often fatal $[3,5]$. Antigens of other blood group systems are not typed unless the units are destined for an alloimmunized patient [6]. In this respect, knowledge about the local distributions of 
wider RBC antigens is important for antibody screening and for searching of compatible blood for these most vulnerable patients [7].

Frequencies of RBC antigens are unique, and considerable differences have been observed between unrelated ethnic groups $[8,9]$. This is because, population events such as founder effects, natural selection, and gene flow may lead to changes of RBC antigen distributions in descendant populations, as compared with their related ancestral populations [10-12]. Two previous studies have reported blood group frequencies for several population groups in Peninsular Malaysia [13, 14]. These include for ABO, $\mathrm{Rh}$, Kell, Kidd, and Duffy blood group frequencies in Malays, Chinese, and Indians. However, other medically relevant blood group systems (e.g. Colton and Dombrock) that are also involved in haemolytic transfusion reaction and gestation incompatibilities were not reported in either [15]. In the study reported here, we provide frequency data of 11 blood group systems screened in 222 unrelated volunteer Malay, Chinese, and Indian blood donors living in Peninsular Malaysia. The extended blood group profiles include their scores for several extra blood group systems (Cartwright, Colton, Dombrock, Lutheran, and Vel) that have not previously been reported [13, 14] can now be used as guidelines for donor recruitment and as a reference standard for studying diseases associated with blood group systems [16, 17].

\section{Methods}

\section{Study population}

Blood samples were obtained from 222 healthy individuals registered as voluntary donors at local blood transfusion units. All volunteers are unrelated and provided their written informed consent. They were then assigned as Malay $(n=97)$, Chinese $(n=77)$, or Indian $(n=48)$ based on their family pedigree as provided (Criterion: 3 generations with no history of intermarriage). Ethical clearance was obtained from the related Ethics Committees (NMRR-16-1399-31311 (IIR) and IRB no: IRB00010568).

\section{Phenotyping of $A B O$ and RhDCE antigens}

The $\mathrm{ABO}$ and $\mathrm{Rh} \mathrm{D}$ blood group antigens were typed using the haemaglutination-based tile method. Antisera for $\mathrm{ABO}$ and $\mathrm{D}$ phenotyping were purchased from bioCSL Pty Ltd. (Parkville, Victoria, Australia), and phenotyping was performed as per the manufacturer's instructions. Other $\mathrm{Rh}$ antigens $(\mathrm{C}, \mathrm{E}, \mathrm{c}, \mathrm{e})$ were determined by tube technique using $5 \%$ unwashed red blood cell suspensions in isotonic saline solution with anti-C, anti-c, anti-E, and anti-e monoclonal antibodies (DIAGAST, Loos, France).

\section{Molecular typing of other blood group systems}

Peripheral blood sample $(50 \mu \mathrm{l})$ was extracted for genomic DNA using Invisorb ${ }^{\bullet}$ Spin Forensic Kit (STRATEC Molecular, Berlin, Germany). Extraction protocols were as per manufacturer's recommendations and as described earlier [18]. Genomic DNA concentration and purity for downstream PCR applications were estimated with Nanodrop 2000c spectrophotometer (Thermo Scientific, MA, USA).

The DNA samples were then typed for Kell, Kidd, Duffy, Cartwright, Dombrock, Colton, Lutheran, Vel, and MNS blood group systems using polymerase chain reaction assays with sequence-specific primer (PCR-SSP) chemistries and protocols as previously reported by Rozman et al. [19], Rink et al. [20] and Heymann et al. [21], respectively. Amplified products were then fractionated by electrophoresis (on $2 \%$ agarose gels stained with ethidium bromide), and PCR product separation patterns were documented by UV photometer (Quantum ST41000/20M, VilberLourmat, Deutschland GmbH, Eberhardzell, Germany). In addition to a pair of primers specific to a particular blood group system, each PCR-SSP reaction mixture also contains a special pair of primers (internal positive control) targeting a 429-bp fragment of the human growth hormone (HGH) gene. Blood group type was then scored based on the size of expected PCRSSP fragment determined using a 100 base pair DNA size standard as a reference (Bioline, London, UK).

\section{Statistical analysis}

Observed phenotype frequencies were obtained by direct counting. Chi-squared $\left(x^{2}\right)$ analyses were used to test for Hardy-Weinberg equilibrium (HWE) using the formula $\chi^{2}=\Sigma\left\{(O-E)^{2} / E\right\}$, where $O$ and $E$ are observed and expected number of phenotypes and expected phenotypes, respectively. Significant departure from HWE is considered at a $P$ value of $<0.05$. This $P$ value was then corrected for multiple comparisons by dividing the standard significant $P$ value $(0.05)$ by the total number of blood group phenotypes [22]. Pairs of blood group datasets were compared using exact test with initial significance value set at $P<0.05$ [23]. This $P$ value $(0.05)$ was then adjusted to $0.005(0.05 / 10$, where 10 is a total number of population datasets included for comparison) using Bonferroni correction. Blood group datasets reported in present and previous surveys [13, 24-27] were mapped on a 2-dimensional principal component plot using the algorithm implemented in Multivariate Statistical Software Package 3 (Kovach Computing Services, UK; http://www.kovcomp.com/mvs).

\section{Results}

Table 1 shows blood group phenotype frequencies determined in 222 Malay, Chinese, and Indian individuals. No 
Table 1 Phenotype frequencies and HWE analysis of blood group systems in Malays, Chinese, and Indians

\begin{tabular}{|c|c|c|c|c|c|c|c|c|c|c|}
\hline Blood system & Phenotype & $\begin{array}{l}\text { Malays } \\
(n=97)\end{array}$ & $x^{2}$ & $P$ & $\begin{array}{l}\text { Chinese } \\
(n=77)\end{array}$ & $x^{2}$ & $P$ & $\begin{array}{l}\text { Indians } \\
(n=48)\end{array}$ & $x^{2}$ & $P$ \\
\hline \multicolumn{11}{|l|}{$\mathrm{ABO}$} \\
\hline & A & 0.320 & 1.448 & 0.694 & 0.200 & 2.699 & 0.440 & 0.250 & 1.669 & 0.643 \\
\hline & B & 0.250 & & & 0.320 & & & 0.190 & & \\
\hline & $A B$ & 0.070 & & & 0.090 & & & 0.080 & & \\
\hline & $\mathrm{O}$ & 0.360 & & & 0.390 & & & 0.480 & & \\
\hline \multicolumn{11}{|l|}{ Rhesus } \\
\hline & DCCEe & 0.031 & 1.563 & 0.955 & 0.030 & 7.042 & 0.317 & 0.020 & 11.158 & 0.084 \\
\hline & DCCee & 0.639 & & & 0.650 & & & 0.540 & & \\
\hline & DCcEE & 0.010 & & & 0.000 & & & 0.000 & & \\
\hline & DCcEe & 0.180 & & & 0.170 & & & 0.150 & & \\
\hline & DccEE & 0.010 & & & 0.060 & & & 0.020 & & \\
\hline & Dccee & 0.000 & & & 0.000 & & & 0.000 & & \\
\hline & DCcee & 0.090 & & & 0.060 & & & 0.210 & & \\
\hline & DccEe & 0.040 & & & 0.030 & & & 0.060 & & \\
\hline \multicolumn{11}{|l|}{ Kell } \\
\hline & $\mathrm{K}+\mathrm{k}-$ & 0.000 & na & na & 0.000 & na & na & 0.000 & na & na \\
\hline & $\mathrm{K}+\mathrm{k}+$ & 0.000 & & & 0.000 & & & 0.000 & & \\
\hline & $\mathrm{K}-\mathrm{k}+$ & 1.000 & & & 1.000 & & & 1.000 & & \\
\hline \multicolumn{11}{|l|}{ Kidd } \\
\hline & $J k(a+b-)$ & 0.340 & 2.893 & 0.495 & 0.210 & 7.042 & 0.317 & 0.300 & 4.714 & 0.194 \\
\hline & $J k(a-b+)$ & 0.190 & & & 0.230 & & & 0.380 & & \\
\hline & $J k(a+b+)$ & 0.440 & & & 0.520 & & & 0.310 & & \\
\hline & $J k(a-b-)$ & 0.040 & & & 0.000 & & & 0.020 & & \\
\hline \multicolumn{11}{|l|}{ Duffy $^{\neq}$} \\
\hline & Fy $(a+b-)$ & 0.750 & 0.696 & 0.706 & 0.900 & 8.469 & 0.014 & 0.560 & 10.705 & 0.005 \\
\hline & Fy $(a-b+)$ & 0.010 & & & 0.000 & & & 0.060 & & \\
\hline & Fy $(a+b+)$ & 0.240 & & & 0.090 & & & 0.380 & & \\
\hline & Fy $(a-b-)$ & 0.000 & & & 0.013 & & & 0.000 & & \\
\hline \multicolumn{11}{|l|}{ MNS } \\
\hline & MNSs & 0.130 & 0.083 & 1.000 & 0.132 & 0.340 & 1.000 & 0.139 & 0.750 & 0.999 \\
\hline & MNS & 0.101 & & & 0.101 & & & 0.100 & & \\
\hline & MNs & 0.209 & & & 0.221 & & & 0.205 & & \\
\hline & MSs & 0.084 & & & 0.078 & & & 0.090 & & \\
\hline & MS & 0.053 & & & 0.048 & & & 0.052 & & \\
\hline & Ms & 0.163 & & & 0.167 & & & 0.156 & & \\
\hline & NSs & 0.070 & & & 0.065 & & & 0.076 & & \\
\hline & NS & 0.040 & & & 0.035 & & & 0.038 & & \\
\hline & Ns & 0.150 & & & 0.154 & & & 0.142 & & \\
\hline \multicolumn{11}{|l|}{ Dombrock } \\
\hline & Do $(a+b-)$ & 0.120 & 1.573 & 0.455 & 0.090 & 0.264 & 0.876 & 0.100 & 1.496 & 0.473 \\
\hline & Do $(a-b+)$ & 0.410 & & & 0.510 & & & 0.560 & & \\
\hline & Do $(a+b+)$ & 0.470 & & & 0.400 & & & 0.340 & & \\
\hline
\end{tabular}

Colton 
Table 1 Phenotype frequencies and HWE analysis of blood group systems in Malays, Chinese, and Indians (Continued)

\begin{tabular}{|c|c|c|c|c|c|c|c|c|c|c|}
\hline Blood system & Phenotype & $\begin{array}{l}\text { Malays } \\
(n=97)\end{array}$ & $x^{2}$ & $P$ & $\begin{array}{l}\text { Chinese } \\
(n=77)\end{array}$ & $x^{2}$ & $P$ & $\begin{array}{l}\text { Indians } \\
(n=48)\end{array}$ & $x^{2}$ & $P$ \\
\hline & Co (a+b-) & 0.990 & & & 1.000 & & & 1.000 & & \\
\hline & Co $(a-b+)$ & 0.000 & na & na & 0.000 & na & na & 0.000 & na & na \\
\hline & $\mathrm{Co}(\mathrm{a}+\mathrm{b}+)$ & 0.010 & & & 0.000 & & & 0.000 & & \\
\hline \multicolumn{11}{|l|}{ Lutheran } \\
\hline & Lu (8+14-) & 1.000 & na & na & 1.000 & na & na & 1.000 & na & na \\
\hline & Lu (8-14+) & 0.000 & & & 0.000 & & & 0.000 & & \\
\hline \multicolumn{11}{|l|}{ Cartwright } \\
\hline & $Y t(a+b-)$ & 1.000 & na & na & 1.000 & na & na & 1.000 & na & na \\
\hline & $Y t(a-b+)$ & 0.000 & & & 0.000 & & & 0.000 & & \\
\hline \multicolumn{11}{|l|}{ Vel } \\
\hline & Vel (+) & 1.000 & na & na & 1.000 & na & na & 1.000 & na & na \\
\hline & Vel $(-)$ & 0.000 & & & 0.000 & & & 0.000 & & \\
\hline
\end{tabular}

$\mathrm{ABO}$ and $\mathrm{Rh} \mathrm{D}, \mathrm{C}, \mathrm{C}, \mathrm{E}$, e were obtained by serological typing, while other blood groups were obtained by PCR-SSR. HWE analysis is considered significantly different if their $P$ value is $<0.050$

$n$ sample size, na not applicable, $P$ significance level ( $P$ value), HWE Hardy-Weinberg equilibrium

${ }^{\ddagger} P$ value for HWE analysis in Duffy blood group was then adjusted to $<0.013$ using Bonferroni correction

significant deviations from HWE were observed except for the Duffy blood group in Chinese and Indians. However, only the latter deviated significantly from HWE after Bonferroni correction. The ABO Type O, DCCee, MNs, and Fy $(\mathrm{a}+\mathrm{b}-)$ phenotypes were recorded to be the most frequent types $(0.360-0.480,0.540-0.650,0.205-$ 0.221 , and $0.560-0.900$, respectively) in all three survey groups. In contrast, the $\mathrm{Jk}(\mathrm{a}+\mathrm{b}+)$ variant of the Kidd blood group system was the most common phenotype in Malays (0.440) and Chinese (0.520), while Jk (a-b+) appears to be the most common phenotype in Indians (0.380). Also, Do $(\mathrm{a}-\mathrm{b}+)$ marker was the most frequently detected Dombrock phenotype in Chinese and Indians ( 0.510 and 0.560 , respectively) compared with Do $(a+b+)$ in Malays (0.470). The Malays, Chinese, and Indians were recorded to be monomorphic for Kell, Lutheran, Cartwright, and Vel blood group systems, where only $\mathrm{K}-\mathrm{k}+, \mathrm{Lu}(8+14)$, Yt (a+b-), and Vel (+) were observed.

Blood group data from the present survey and those from earlier studies conducted by Abd Gani et al. [14] and Musa et al. [13] are compared and listed in Table 2. As mentioned earlier, only ABO, Rhesus, Kell, Kidd, Duffy, and MNS were reported in the earlier surveys and available for comparison with ours. Some differences were observed between these blood group datasets especially for the ABO, Kell, and Kidd blood groups. For instance, ABO Type B blood group is the most common one found in Banjar and Maindailing Malays as compared with $\mathrm{ABO}$ Type $\mathrm{O}$ in Malays participating in the present study. In addition, $\mathrm{K}+\mathrm{k}-, \mathrm{K}+\mathrm{k}+$, and $\mathrm{K}-\mathrm{k}+$ phenotypes of Kell blood group and Rhesus negative were detected in the Malay, Chinese, and Indian subjects reported by Musa et al. [13], but only the $\mathrm{K}-\mathrm{k}+$ and
Rhesus positive phenotypes were recorded in the present study and previous report on the Malay sub-ethnic groups [14]. Exact test of population differentiations for each blood group system (ABO, Rhesus, Kell, Kidd, and Duffy) and each pair of datasets listed in Table 2 are shown in online supplementary Table S1. There are no significant differences between the Malays in the present study vs. other ethnically similar datasets from previous surveys $[13,14]$. However, many significant differences were recorded between blood group datasets for ethnically unrelated populations (Malays vs. Chinese vs. Indians) especially for Rhesus, Kidd, and Duffy blood group systems.

The PCA plot was constructed using ABO, Rhesus, and MNS frequency data (online supplementary Table S2) from present and previous surveys [13, 24-27] are shown in Fig. 1. A total of $60 \%$ of genetic variability between these blood group datasets was accounted for (42\% for axis 1 and 18\% for axis 2). Generally, population groups from Peninsular Malaysia plot closely, regardless of their ethnicity and are separated from population groups belonging to Europe and Oceania.

\section{Discussion}

Peninsular Malaysia is a region occupied by a diverse range of human population groups including Malays, Chinese, Indians, and three Orang Asli groups (Semang, Senoi, and Proto-Malays). Multidisciplinary data have shown different ancestral sources for the three divisions of Orang Asli [28-30]. The Semang represent descendants of the first 'Out of Africa' lineage of Homo sapiens migrants [31, 32], the Senoi come from the north and share greater affinities with populations in Indo-China 


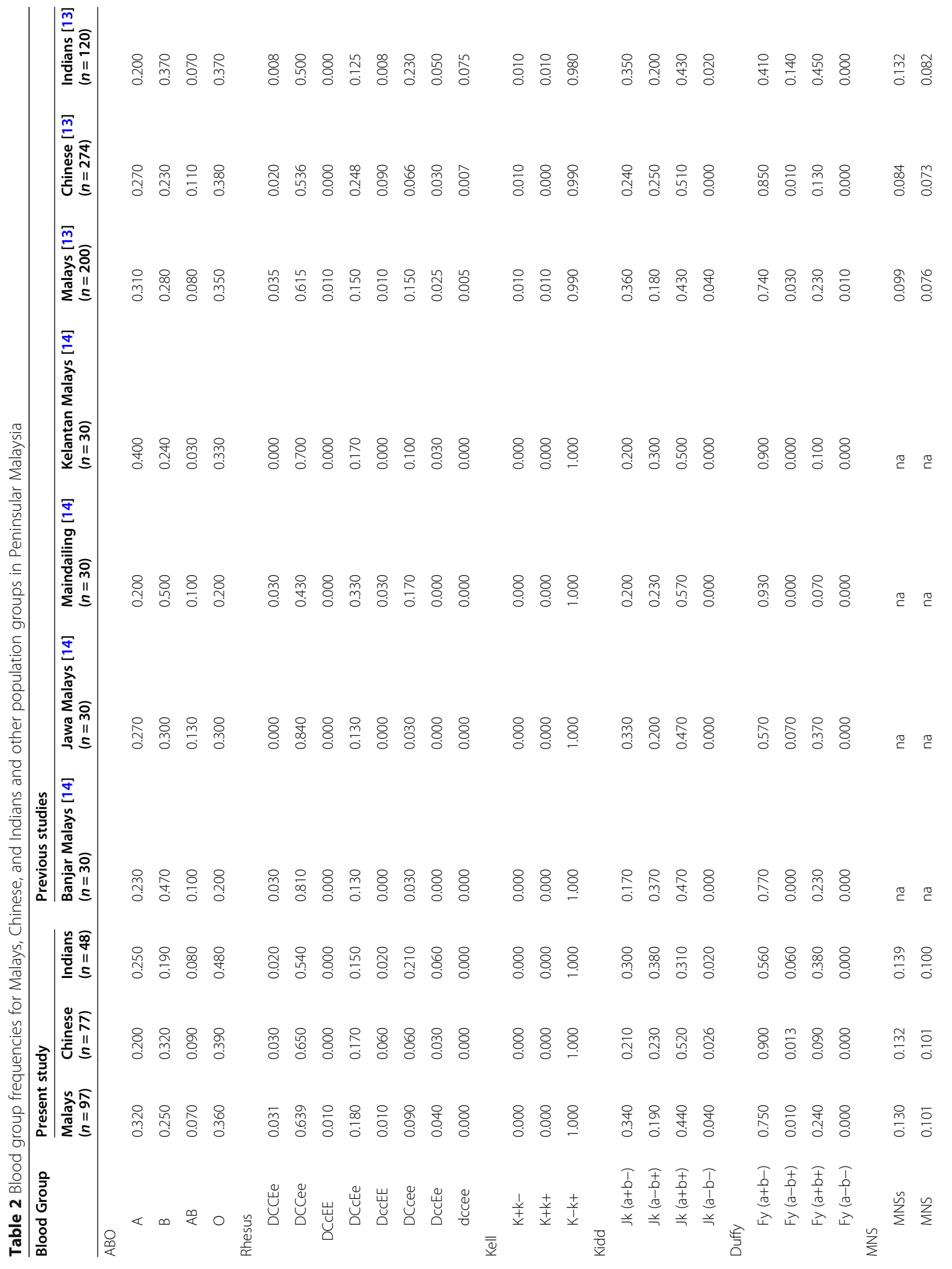




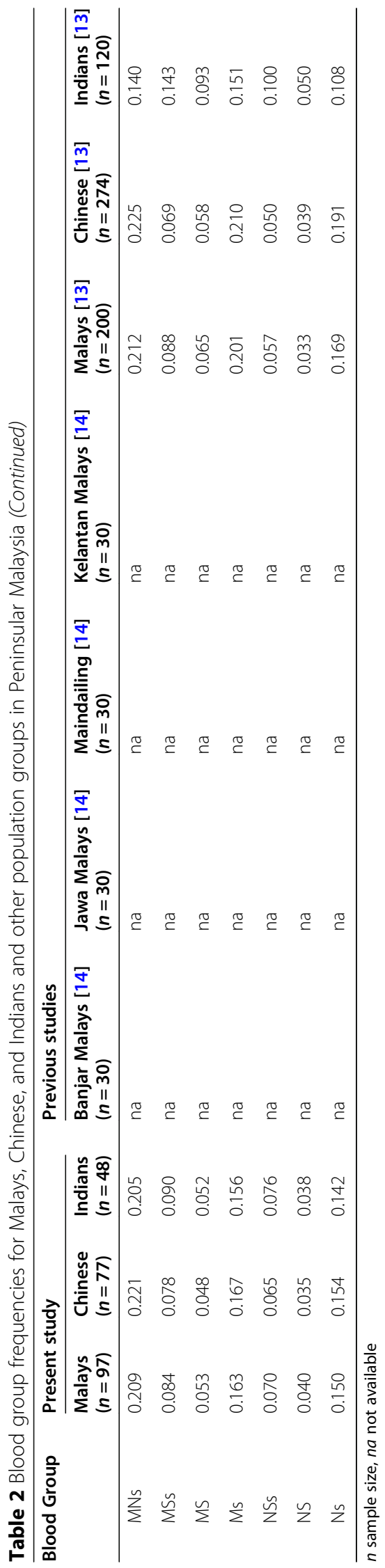




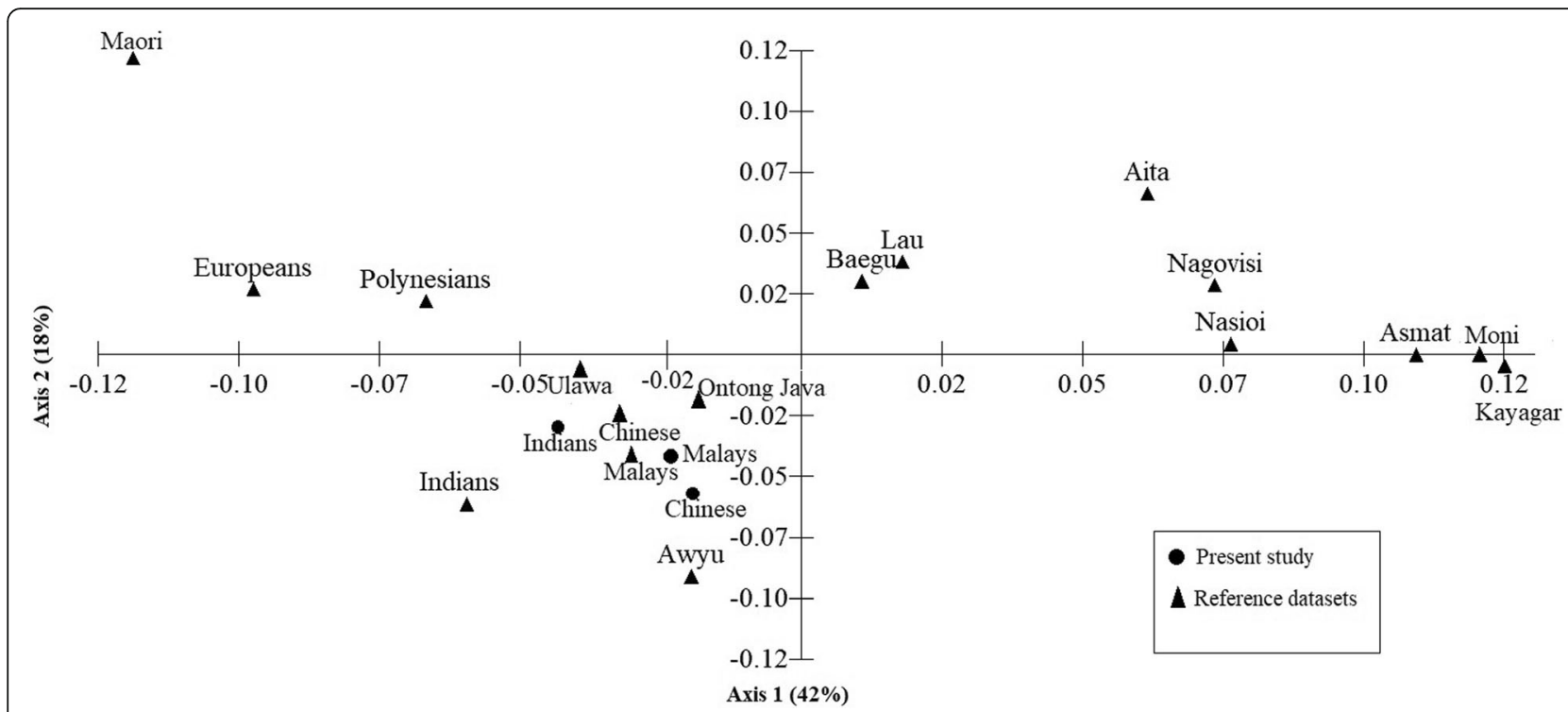

Fig. 1 Principal component plot constructed using ABO, Rhesus, and MNS blood group frequency data

[33], whereas the Proto-Malays are linked to putative Austronesian ancestors in Taiwan [34]. In contrast, several other Austronesian Malay sub-ethnic groups including Jawa, Banjar, Bugis, Minangkabau, and Rawa migrated to Peninsular Malaysia as recently as around 300-400 years ago from nearby regions like Java, Kalimantan, Sulawesi, and Sumatera [35].

The Orang Asli and a few of the Malay sub-ethnic groups have now become significant minorities in Peninsular Malaysia [36]. The Malays themselves represent $60 \%$ of the Malaysian population and are inferred on the basis of genetic evidence to have arisen from ProtoMalays by admixture with Malay sub-ethnic groups and other ethnicities. The latter include Chinese and Indians who settled in Peninsular Malaysia during historic times via large-scale migration during the British colonial era in the 19th century [37-39].

Blood group data for the Malays generated from the present study (Table 1) showed no significant differences between the Malays and Malay sub-ethnic groups (Table 2 and online supplementary Table S1) reported by Musa et al. [13] and Abd Ghani et al. [14]. These findings support a close genetic relationship between these ancestrally related populations as inferred from other studies [40]. However, we observed significant differences between the Malays vs. both Chinese and Indians (online supplementary Table S1). This is not surprising as these populations are ancestrally unrelated. In addition, the gene pool of present day population groups in Peninsular Malaysia might have been further shaped by evolutionary processes such as natural selection and gene flow since they settled in Peninsular Malaysia. In particular, a significant deviation from HWE was found for the Duffy blood group system in Indians even after Bonferroni correction (Table 1). This observation might be associated with the relatively small number of Indian individuals included in the present survey as well as the effects of natural selection. Several Duffy blood group phenotypes are known to be associated with diseases $[41,42]$ and identified as receptors for malarial parasites [43]. However, differences between population groups in Peninsular Malaysia were not so obvious in the PCA analysis due to scaling issues (Fig. 1). Here, the Malays, Chinese, and Indians are plotted together and are well separated with the population groups from other geographical regions (Europe and Oceania). The Malays are also separated with their other linguistically related populations including Maori and Polynesians. Here we note that evidence from multidisciplinary studies do show a common origin for these Austronesian-speaking populations [26, 44-49]. They are all descendants of Taiwan aboriginals who migrated out into the Asia-Pacific region 5000-7000 years ago $[50,51]$. It can be concluded that our new blood group data reflect geographical proximity and ancestral relationships. However, our findings should be interpreted with some caution as the PCA analysis was carried out using only data for three of their blood group systems (ABO, Rhesus, and MNS) as many of the other blood group systems were not characterized in the available reference populations.

Blood group population datasets reported here including those from the previous studies $[13,14]$ are of medical significance as blood group antigens are 
determinants of transfusion and gestation compatibilities. The data show the polymorphic nature of blood group systems in various population groups in Malaysia (Tables 1 and 2). These include those blood group systems that are reported for the first time here such as Dombrock and Colton. Other blood group systems in Malays, Chinese, and Indians are monomorphic, but we cannot rule out that they might actually be polymorphic with rare low-frequency alleles, and further work using larger sample sizes are needed to reveal the true extent of allelic variations in Malaysia. Nonetheless, the available blood group data showed that there are potential risks of transfusion and gestation alloimmunization in Malaysia, particularly for polymorphic blood group systems like ABO, Rhesus, Kell, Kidd, Duffy, MNS, Colton, and Dombrock. Our predictions are supported by Al-Joudi et al. [52] and Ismahanisa Ismail et al. [53] where alloantibodies against $\mathrm{ABO}$, Rhesus, Kidd, and Duffy antigens are commonly observed among transfused patients in Malaysia.

Overall, our study further supports the importance of blood group data for studying ancestry and health [43]. Several issues and limitations highlighted here including the availability or otherwise of reference population datasets for comparison purposes, number of blood group loci screened in the earlier studies [13, 14] and sample size can be used as guidelines for future study of blood groups in other populations, including in Malaysia [54]. Nonetheless, some blood group datasets including those for Cartwright, Colton, Dombrock, Lutheran, and Vel in Malays, Chinese, and Indians were reported here for the first time and should provide important information for building better healthcare services (e.g. an improved pool of blood group-typed donors and for prenatal screening) in Peninsular Malaysia and can be used as reference datasets for future investigations of diseases associated with blood groups [3, 41, 53].

\section{Conclusions}

Overall, our present study has successfully provided extended blood group profiles for Malays, Chinese, and Indians in Peninsular Malaysia. Our statistical analyses have revealed marked differences between the new and previously reported blood group datasets. These observations support the picture of complex genetic structure present in Peninsular Malaysia. The new blood group datasets reported here can be used to guide for donor recruitment strategies and provide an important and expanded reference standard for studying diseases associated with blood group systems.

\section{Supplementary information}

Supplementary information accompanies this paper at https://doi.org/10. 1186/s43042-020-00096-y.

Additional file 1: Table S1. Exact tests population differentiation $(P$ value) between pairs of population groups in Peninsular Malaysia.

Additional file 2: Table S2. Blood group frequency data used for PCA data mapping.

\section{Abbreviations}

RBCs: Red blood cells; PCA: Principal component analysis; ISBT: International Society of Blood Transfusion; Rh: Rhesus; PCR-SSP: Polymerase chain reaction reaction-sequence-specific primer; $\mathrm{HGH}$ : Human growth hormone;

HWE: Hardy-Weinberg equilibrium; $n$ : Sample size; na: Not available; na: Not available/applicable

\section{Acknowledgements}

We acknowledge with thanks all the participants who voluntarily donated their blood and the invaluable help and assistance given by doctors and nurses during sample collection. Geoffrey K. Chambers thanks Victoria University of Wellington for Alumnus Scholar support.

\section{Authors' contributions}

CGNH designed and performed the research, collected the data, analysed the data, and prepared, edited, and reviewed the manuscript. ZZ helped to design the study, data acquisition, and obtained ethical permit from the Ministry of Health, Malaysia, NSMR, and THTM helped with study design, sampling, and data collection. PP help performed the experiment. MNH, SF, GEG, and GKC designed the research, advised on statistics and edited the manuscript, and HAE designed the research, advised on statistics, edited the manuscript, funded the research, and obtained ethical approval from Human Ethics Committee, Universiti Sains Malaysia. The authors have read and approved the final manuscript.

\section{Funding}

We are most grateful to the Universiti Sains Malaysia (USM) for research facilities and financial support (Short Term Grant: 304/PPSK/6315142 and Bridging Grant: 304/PPSK 6316132).

\section{Availability of data and materials}

All data generated or analysed during this study are included in this published article (and its supplementary information files).

\section{Ethics approval and consent to participate}

This study was conducted in accordance with relevant ethical standards, and the study protocol was approved (USM/JEPeM/16050191) by the Human Research Ethics Committee of University Sains Malaysia (registered as IRB no: IRB00010568) and the Medical Research and the Ethics Committee, Ministry of Health, Malaysia (NMRR-16-1399-31311 (IIR)), and the subjects have signed and informed written consent.

\section{Consent for publication}

Not applicable

\section{Competing interests}

The authors declare that they have no competing interests.

\section{Author details}

${ }^{1}$ School of Health Sciences, Universiti Sains Malaysia, Health Campus, Kubang Kerian, Kelantan, Malaysia. ${ }^{2}$ Hospital Universiti Sains Malaysia, Universiti Sains Malaysia, Kubang Kerian, Kelantan, Malaysia. ${ }^{3}$ School of Medical Sciences, Universiti Sains Malaysia, Health Campus, Kubang Kerian, Kelantan, Malaysia. ${ }^{4}$ Hospital Sultan Haji Ahmad Shah, Temerloh, Pahang, Malaysia. ${ }^{5}$ Hospital Seberang Jaya, Perai, Pulau Pinang, Malaysia. ${ }^{6}$ Department of Immunology, Pathology and Laboratory Medicine Services, Sheikh Khalifa Medical City, Abu Dhabi, United Arab Emirates. ${ }^{7}$ School of Biological Sciences, Victoria University of Wellington, Wellington, New Zealand. ${ }^{8}$ Environmental Futures Research Institute, Griffith University, Nathan, Queensland, Australia. ${ }^{9}$ Institute of Tropical Biodiversity and Sustainable Development, Universiti Malaysia Terengganu, Kuala Nerus, Terengganu, Malaysia. 
Received: 24 April 2020 Accepted: 1 September 2020

Published online: 01 December 2020

\section{References}

1. Dean $L$ (2005) Blood groups and red cell antigens. National Center for Biotechnology Information, Bethesda, Maryland

2. Osaro E, Tosan E, Charles AT, Polycarp II (2019) Distribution of clinically relevant blood group antigens among Nigerians and the management of rhesus D negative pregnancies: implications for haemolytic disease of the foetus and newborn and haemolytic transfusion reactions. IntechOpen. https://doi.org/10.5772/intechopen.90372

3. Norfolk D (2014) Handbook of transfusion medicine, 5th edn. United Kingdom Blood Services, London

4. International Society of Blood Transfusion. http://isbtweb.org/workingparties/red-cell-immunogenetics-and-blood-group-terminology/. Accessed 12 Aug 2020.

5. Daniels G, Castilho L, Flegel W, Fletcher A, Garratty G, Levene C et al (2009) International society of blood transfusion committee on terminology for red blood cell surface antigens: Macao report. Vox Sang 96(2):153-156

6. Bakanay SM, Ozturk A, lleri T, Ince E, Yavasoglu S, Akar N et al (2013) Blood group genotyping in multi-transfused patients. Transfus Apher Sci 48(2): 257-261

7. Worlledge S, Ogiemudia S, Thomas C, Ikoku B, Luzzatto L (1974) Blood group antigens and antibodies in Nigeria. Ann Trop Med Parasitol 68(3): 249-264

8. Garratty G, Glynn SA, McEntire R, Study RED (2004) ABO and Rh (D) phenotype frequencies of different racial/ethnic groups in the United States. Transfusion 44(5):703-706

9. Golassa L, Tsegaye A, Erko B, Mamo H (2017) High rhesus (Rh (D)) negative frequency and ethnic-group based $\mathrm{ABO}$ blood group distribution in Ethiopia. BMC Res Notes 10(1):330

10. Halverson MS, Bolnick DA (2008) An ancient DNA test of a founder effect in native American $\mathrm{ABO}$ blood group frequencies. Am J Phys Anthropol 137(3):342-347

11. Salzano FM (1963) Blood groups and gene flow in negroes from southern Brazil. Acta Genet Stat Med 13(1):9-20

12. Hodgson JA, Pickrell JK, Pearson LN, Quillen EE, Prista A, Rocha J et al (2014) Natural selection for the Duffy-null allele in the recently admixed people of Madagascar. Proc Biol Sci 281(1789):20140930

13. Musa RH, Ahmed SA, Hashim H, Ayob Y, Asidin NH, Choo PY et al (2012) Red cell phenotyping of blood from donors at the National Blood Center of Malaysia. Asian J Transfus Sci 6(1):3-9

14. Abd Gani R, Manaf SM, Zafarina Z, Panneerchelvam S, Chambers GK, Norazmi MN et al (2015) Molecular blood group typing in Banjar, Jawa, Mandailing and Kelantan Malays in peninsular Malaysia. Transfus Apher Sci 53(1):69-73

15. Hong YJ, Chung Y, Hwang SM, Park JS, Kwon JR, Choi YS et al (2016) Genotyping of 22 blood group antigen polymorphisms and establishing a national recipient registry in the Korean population. Ann Hematol 95(6): 985-991

16. Bailey DJ, Westhoff CM (2019) Chapter 30 - other blood group systems, collections, and series. In: Beth HS, Christopher DH, Mikhail R, Charles SA et al (eds) Transfusion medicine and hemostasis, 3rd edn. Elsevier Science, London, pp 177-184

17. Yan L, Zhu F, Fu Q, He J (2005) ABO, Rh, MNS, Duffy, Kidd, Yt, Scianna, and Colton blood group systems in indigenous Chinese. Immunohematology 21(1):10-14

18. Hajar CGN, Zulkafli Z, Md Riffin NS, Tuan Mohammad TH, Safuan S, Nelson BR et al (2019) Human neutrophil antigen frequency data for Malays. Chinese and Indians Transfus Apher Sci 59:102651

19. Rozman P, Dovc T, Gassner C (2000) Differentiation of autologous ABO, RHD, RHCE, KEL, JK, and FY blood group genotypes by analysis of peripheral blood samples of patients who have recently received multiple transfusions. Transfusion, 40(8):936-942

20. Rink G, Scharberg EA, Bugert P (2015) PCR with sequence-specific primers for typing of diallelic blood groups. In: Molecular typing of blood cell antigens. Springer, Champ, pp 71-81

21. Heymann GA, Salama A (2010) Sequence-specific primers for MNS blood group genotyping. Blood Transfus 8(3):159-162

22. Louis EJ, Dempster ER (1987) An exact test for hardy-Weinberg and multiple alleles. Biometrics 43:805-811
23. Excoffier L, Laval G, Schneider S (2006) ARLEQUIN version 3.1: a software for population genetic data analysis. In: Computational and molecular population genetics laboratory, Institute of Zoology, University of Berne, Switzerland

24. Gajdusek DC, Leyshon WC, Kirk RL, Blake NM, Keats B, McDermid EM (1978) Genetic differentiation among populations in Western New Guinea. Am J Phys Anthropol 48(1):47-63

25. Grunbaum BW, Selvin S, Myhre BA, Pace N (1980) Distribution of gene frequencies and discrimination probabilities for 22 human blood genetic systems in four racial groups. J Forensic Sc 25(2):428-444

26. Lai LY, Bloom J (1982) Genetic variation in Bougainville and Solomon Islands populations. Am J Phys Anthropol 58(4):369-382

27. Edinur HA, Dunn PP, Lea RA, Chambers GK (2013) Molecular approaches to transfusion medicine in Polynesians and Maori in New Zealand. Int J Immunogenet 40(6):460-470

28. Chambers GK, Edinur HA (2013) Genetic relationships between Malays and Maori. In: Rahman WRA, Higgins TR (eds) The changing values of Malays, Maori and Pacific islanders. Chair of Malay Studies \& Victoria University Foundation, Wellington, pp 6-37

29. Chambers GK, Edinur HA (2015) The Austronesian diaspora: a synthetic total evidence model. G J Anthropol Res 2(2):53-65

30. Zahidin MA, Omar WBW, Taib WRW, Japning JRR, Abdullah MT (2018) Sequence polymorphism and haplogroup data of the hypervariable regions on mtDNA in Semoq Beri population. Data Brief 21:2609-2615

31. Bellwood P (2007) Prehistory of the indo-Malaysian archipelago, 3rd edn. ANU Press, Canberra

32. Macaulay V, Hill C, Achilli A, Clarke D, Meehan W, Blackburn J et al (2005) Single, rapid coastal settlement of Asia revealed by analysis of complete mitochondrial genomes. Science 308(5724):1034-1036

33. Baer AS (1999) Health, disease, and survival: a biomedical and genetic analysis of the orang Asli of Malaysia. Center for Orang Asli Concerns, Subang Jaya

34. Fix AG (1995) Malayan paleosociology: implications for patterns of genetic variation among the orang Asli. Am Anthropol 97(2):313-323

35. Hatin WI, Nur-Shafawati AR, Zahri MK, Xu S, Jin L, Tan SG et al (2011) Population genetic structure of peninsular Malaysia Malay sub-ethnic groups. PLoS One 6(4):e18312

36. Sainuddin S (2003) Titas Tamadun Melayu (Malay civilization Titas). Quantum Books, Perak

37. Nagaraj S, Lee KH, Tey NP, Ng W, Pala J (2009) Counting ethnicity in Malaysia: the complexity of measuring diversity. Malays J Econ Stud 46(1):5-32

38. Cavendish M (2008) The world and its peoples: Malaysia, Singapore, Brunei and the Philippines. Marshall Cavendish Corp, New York

39. Hock SS (2007) The population of peninsular Malaysialnstitute of Southeast Asian Studies

40. Edinur HA, Zafarina Z (2009) Spiola, Nurhaslindawaty AR, Panneerchelvam S, Norazmi MN. HLA polymorphism in six Malay subethnic groups in Malaysia. Hum Immunol 70(7):518-526

41. Anstee D (2010) The relationship between blood groups and disease. Blood 115(23):4635-4643

42. Horne K, Woolley IJ (2009) Shedding light on DARC: the role of the Duffy antigen/receptor for chemokines in inflammation, infection and malignancy. Inflamm Res 58(8):431-435

43. Saleh RM, Zefarina Z, Mat NFC, Chambers GK, Edinur HA (2018) Transfusion medicine and molecular genetic methods. Int J Prev Med 9(1):45

44. Edinur HA, Dunn PP, Hammond L, Selwyn C, Velickovic ZM, Lea RA et a (2012) Using HLA loci to inform ancestry and health in Polynesian and Maori populations. Tissue Antigens 80(6):509-522

45. Edinur HA, Dunn PP, Lea RA, Chambers GK (2013) Human platelet antigen frequencies in Maori and Polynesian populations. Transfus Med 23(5):330-337

46. Wan Syafawati WU, Norhalifah HK, Zefarina Z, Zafarina Z, Panneerchelvam S, Norazmi MN et al (2015) Allele frequencies of human platelet antigens in Banjar, Bugis, Champa, Jawa and Kelantan Malays in peninsular Malaysia. Transfus Med 25(5):326-332

47. Manaf SM, NurWaliyuddin HZ, Panneerchelvam S, Zafarina Z, Norazmi MN, Chambers GK et al (2015) Human neutrophil antigen profiles in Banjar, Bugis, Champa, Jawa and Kelantan Malays in peninsular Malaysia. Blood Transfus 13(4):610-615

48. Norhalifah HK, Zafarina Z, Sundararajulu P, Norazmi MN, Edinur HA (2015) Distribution of cytokine gene polymorphisms in five Malay subethnic groups in peninsular Malaysia. Int J Immunogenet 42(3):200-203 
49. Bellwood P, Chambers GK, Ross M, Hung H-C (2011) Are 'cultures' inherited? Multidisciplinary perspectives on the origins and migrations of Austronesian-speaking peoples prior to 1000 BC. In: Roberts BW, Marc VL (eds) Investigating archaeological cultures. Springer, Cham, pp 321-354

50. Norhalifah HK, Syaza FH, Chambers G, Edinur HA (2016) The genetic history of peninsular Malaysia. Gene 586(1):129-135

51. Chambers GK, Edinur HA, Dunn PP (2016) New insights into ancestry and health of Polynesians and New Zealand Maori. New Zealand Sci Rev 73(1): 3-10

52. Al-Joudi F, Ali AB, Ramli MB, Ahmed S, Ismail M (2011) Prevalence and specificities of red cell alloantibodies among blood recipients in the Malaysian state of Kelantan. Asian J Transfus Sci 5(1):42-45

53. Ismahanisa Ismail W, Al-Hassan FM, Shatar A, Roslan M, Rosdan NH, Zainuddin N et al (2016) Prevalence of red cell alloantibodies among multi transfused dependent thalassemia patient in the Malaysian state of Penang. J Sci Res Development 3:62-66

54. Hakim HM, Lalung J, Narayanen S, Khaw NR, Chamber GK, Edinur HA (2018) A new analysis of population history in Sabah and Sarawak. Global J Bus Soc Sci Review 6(4):106-113

\section{Publisher's Note}

Springer Nature remains neutral with regard to jurisdictional claims in published maps and institutional affiliations.

\section{Submit your manuscript to a SpringerOpen ${ }^{\circ}$ journal and benefit from:}

- Convenient online submission

- Rigorous peer review

- Open access: articles freely available online

High visibility within the field

- Retaining the copyright to your article

Submit your next manuscript at $\boldsymbol{\nabla}$ springeropen.com 